\title{
Lectin-oral streptococci interactions
}

\author{
WHINGMING LEE, ANNA MARIÁ CALDERON DE LA BARCA*, D. DRAKE† and R. J. DOYLE \\ Department of Microbiology and Immunology, University of Louisville, Health Science Center, Louisville, \\ KY 40292, *CIAD, Hermosillo, Son., Mx and †Dows Research Institute, University of lowa, lowa City, IA, \\ USA
}

\begin{abstract}
Lectins of various specificities were examined for interaction with strains of oral streptococci of various species. The lectins were capable of binding galactose, $N$ acetylgalactosamine, glucose, $N$-acetylglucosamine, mannose, fucose and sialic acid. Lectin reactivities were strain-dependent in that some members of a species, but not others, could be aggregated by certain lectins. Proteolysis and extraction with hot water, guanidine hydrochloride and sodium dodecyl sulphate tended to increase the reactivity of the streptococci with lectins but did not change the recognition patterns of the bacteria. Sonication, in contrast, tended to reduce the ability of streptococci to be agglutinated by lectins. Furthermore, lectin reactivities were dependent on the growth conditions, as evidenced by changes in lectin titres following streptococcal growth in subinhibitory concentrations of citrate, fluoride or antibiotics. It is likely that lectins could be useful tools for epidemiological studies and to probe strain-dependent and growthdependent surface characteristics of viridans streptococci.
\end{abstract}

\section{Introduction}

In microbiology, lectins have assumed an important role in studying glycoconjugates and microbial cell surfaces. In bacteria, there are several glycoconjugates capable of serving as receptors for lectins. These include peptidoglycans (PG), teichoic acids, lipoteichoic acids, teichuronic acids, capsules, surface arrays, glycoproteins (unusual in most prokaryotes), glycolipids, lipopolysaccharides and secreted polysaccharides. In theory, any glycoconjugate may act as a receptor, provided that a lectin of the proper specificity can be identified.

One particular use of lectins in microbiology has been in laboratory diagnostic microbiology [1-5]. Thus, the binding of a particular isolate by a particular lectin may be used to identify the organism. There are numerous reports of the uses of lectins in diagnostic microbiology. A gram-negative diplococcus growing on Thayer-Martin medium and capable of being aggregated by $5-10 \mu \mathrm{g}$ of wheat-germ agglutinin (WGA) is either Neisseria gonorrhoeae or untypable $N$. meningitidis [6]. The latter organism is quickly identified by the presence of $\gamma$ glutamyl-aminopeptidase [5]. Also, Campylobacter spp., for example, can

Received 23 Sept. 1996; revised verison received 19 May 1997; accepted 22 May 1997.

Corresponding author: Professor R. J. Doyle. be distinguished by lectins [7]. Not only are lectins important as diagnostic probes, the proteins are useful in epidemiological studies, in which lectin reactivity is dependent on the geographic source of the isolate $[8$, 9].

The aim of this research was to determine if lectins could be employed as reagents for oral streptococci. It is already known that some streptococci possess receptors for lectins. Other research has shown that streptococcal polymers, such as lipoteichoic acids from Enterococcus faecalis and E. hirae, bind avidly to concanavalin A (Con A)-agarose columns, the avidity of which is a function of polymer glucosylation [10]. In group A streptococci, Con A coupled with ferritin has been used as a probe for lipoteichoic acid on the cell surface [11]. In group C streptococci, the lectin from Helix pomatia (HPA) offers a selective reagent for cell aggulintation [12, 13]. Wheat-germ agglutinin (WGA, see Table 1 for abbreviations) offers a convenient probe for various streptococcal polymers [14]. Kashket and Guilmette [15] observed that several oral streptococci could be readily aggregated by Con A, but dextranase treatment of the bacteria reduced the interaction with the lectin. Studies by Hamada et al. [16] revealed that lectins capable of binding to oral streptococci could reduce the adhesion of the bacteria to saliva-coated hydroxylapatite.

This study was performed to discover if a particular lectin, or group of lectins, can agglutinate particular 
oral streptococci. This knowledge may be useful in studying the distribution of the bacteria in the oral cavity, and lectins may prove to be of use in the study of the epidemiology of caries in various populations.

\section{Materials and methods}

\section{Bacterial strains}

A collection of 20 strains of 10 species of oral streptococci and one strain of E. faecalis was used for this study. Bacteria were obtained from the American Type Culture Collection or from Professor A. Bleiweis, University of Florida (USA). Stock cultures were maintained in Tryptic Soy Broth (TSB; Sigma) at $-70^{\circ} \mathrm{C}$ and were streaked on Mitis-Salivarius (MS) agar (Difco Laboratories) to obtain isolated colonies. Gram-staining and the catalase test were performed routinely to identify organisms presumptively as streptococci. Classical biochemical tests were used to confirm the identity of the bacteria [17-19]. The streptococci were cultured in TSB; before autoclaving, the broth was incubated with fungal dextranase (Sigma; 0.65 units of enzyme preparation/g of dry medium) at $37^{\circ} \mathrm{C}$ for $2 \mathrm{~h}$ and with yeast invertase $(0.2 \mathrm{mg} / \mathrm{g}$ of dry medium) at $55^{\circ} \mathrm{C}$ for $2 \mathrm{~h}$ to remove any sucrose or dextran, known to promote autoagglutination [20].

\section{Culture (growth) conditions}

Isolated colonies of oral streptococci from MS agar plates were subcultured in TSB, incubated statically at $37^{\circ} \mathrm{C}$ in an aerobic atmosphere supplemented with $\mathrm{CO}_{2}$ $5 \%$ overnight for $c .18 \mathrm{~h}$ to late exponential phase. The bacteria were then harvested by centrifugation (Sorvall RC-5B refrigerated superspeed centrifuge, Newtown, CT, USA) at $10000 \mathrm{~g}$ for $5 \mathrm{~min}$ and washed twice with phosphate-buffered saline (PBS; $20 \mathrm{mM}$ sodium phosphate $150 \mathrm{mM}$ sodium chloride, $\mathrm{pH} 7.3$ ). Bacterial cell pellets were then suspended in PBS to an appropriate optical density, judged by absorbance at $540 \mathrm{~nm}$ (Milton Roy Spectronic 21D, Rochester, USA).

\section{Plant lectins}

The lectins used were selected on the basis of their reported specificities to cover the widest possible range of carbohydrates (Table 1). All lectins were commercially available from E-Y Laboratory (San Mateo, CA, USA) and Lectinola (Charles University, Prague, Czech

Table 1. Panel of lectins*

\begin{tabular}{|c|c|c|}
\hline Systematic name & Abbreviation and common name & Sugar specificities \\
\hline Abrus precatorius & APA (jequirty bean) & $\beta$-D-Gal $>\alpha$-D-GalNAc \\
\hline Agaricus bisporus & ABA (mushroom) & $\mathrm{Gal} \beta-1,3 \mathrm{GalNAc} ; \mathrm{Gal}$ \\
\hline Anguilla anguilla & AAA (fresh water eel) & L-Fuc $\alpha-1,3 \mathrm{Gal}[$ Anti-O(H)] \\
\hline Arachis hypogaea & PNA (peanut) & Gal $\beta$-1,3-GalNAc; Gal (Anti- $\mathrm{T}_{1} \mathrm{~T}_{\mathrm{k}}, \mathrm{T}_{\mathrm{h}}, \mathrm{T}_{\mathrm{x}}$ ) \\
\hline Artocarpus integrifolia & AIA (jackfruit) & Gal $\beta-1,3$ GalNAc (Anti-T) \\
\hline Bauhinia purpurea & BPA (camel's foot tree) & $\mathrm{Gal} \beta-1,3 \mathrm{GalNAc} ; \mathrm{Gal} \beta-1,3 \mathrm{Gal}$ (Anti-T) \\
\hline Canavalia ensiformis & Con A (jack bean) & Man $\alpha-1 ;$ Glc $\alpha-1 ;$ GlcNAc $\alpha-1$ \\
\hline Datura stramonium & DSA (jimson weed) & $\mathrm{Gal} \beta-1,3$ (4) GlcNAc \\
\hline Dolichos biflorus & DBA (horse gram) & GalNAc $\alpha-1,3$ GalNAc (Anti-A $\mathrm{A}_{1}>\mathrm{A}_{2}>\mathrm{Cad}$ ) \\
\hline Erythrina cristagalli & ECA (coral tree) & $\mathrm{Gal} \beta$-1,4GlcNAc; Gal $\alpha 1,6 \mathrm{Gal} ; \mathrm{Gal}$ \\
\hline Euonymus europaeus & EEA (spindle tree) & Complex \\
\hline Galanthus nivalis & GNA (snowdrop bulb) & D-Mannose \\
\hline Glycine $\max$ & SBA (soybean) & GalNAc $\alpha$ (or $\beta$ ) $1,3 \mathrm{Gal} ; \mathrm{D}-\mathrm{Gal}$ \\
\hline Griffonia simplicifolia I & GSA-I (African legume) & $\alpha$-D-Gal; D-GalNAc (Anti A, B) \\
\hline Griffonia simplicifolia $I I$ & GSA-II (African legume) & D-GlcNAc (Anti-B, $\left.\mathrm{T}_{\mathrm{k}}, \mathrm{T}\right)$ \\
\hline Helix aspersa & HAA (garden snail) & $\alpha$-D-GalNAc (Anti-A) \\
\hline Helix pomatia & HPA (edible snail) & $\alpha$-D-GalNAc $\alpha-1,3$ GalNAc \\
\hline Laburnum alpinum & LAA (Scotch laburnum) & L-Fuc $\alpha-1,2 \mathrm{Gal}[\mathrm{Anti}-\mathrm{O}(\mathrm{H})]$ \\
\hline Lens culinaris & LCH (lentil) & $\operatorname{Man} \alpha-1 ; \operatorname{Glc} \alpha-1$ \\
\hline Limax flavus & LFA (garden slug) & Sialic acid \\
\hline Limulus polyphemus & LPA (horseshoe crab) & Sialic acid \\
\hline Lycopersicon esculentum & LEA (tomato) & $(\mathrm{GlcNAc} \beta-1,4) \mathrm{n}$ \\
\hline Maackia amurensis & MAA & Sialic acid \\
\hline Maclura pomifera & MPA (osage orange) & $\mathrm{Gal} \beta-1,3 \mathrm{GalNAc}$ (Anti-T) \\
\hline Misgunnus anguillicaudatus & Loach & L-Rhamnose \\
\hline Phaseolus lunatus & LBA (lima bean) & $\alpha$-D-GalNAc $\alpha-1,3 \mathrm{Gal}$ \\
\hline Phaseolus vulgaris & PHA-E (red kidney bean) & Complex \\
\hline Phytolacca americana & PWA (pokeweed) & $\mathrm{Gal} \beta-1,4$ (3) GlcNAc; (GlcNAc, $\beta-1,4) \mathrm{n} ;$ Man $\alpha-1,2 \mathrm{Man}$ \\
\hline Pisum sativum & PEA (garden pea) & Man $\alpha-1 ;$ Glc $\alpha-1$ \\
\hline Ricinus communis & RCA-I, II (castor bean) & Gal $\beta-1,3$ (4) GlcNAc; Gal $\beta-1,3$ GalNAc; GalNAc \\
\hline Robinia pseudoacacia & RPA (black locust) & Complex \\
\hline Solanum tuberosum & STA (potato) & $(\text { GlcNAc } \beta-1,4)_{2-5}$ \\
\hline Sophora japonica & SJA (pagoda tree) & $\mathrm{Gal} \beta-1,3 \mathrm{GalNAc} ; \mathrm{Gal} \beta-1,3 \mathrm{GlcNAc}$ \\
\hline Triticum vulgaris & WGA (wheat-germ) & $(\text { GlcNAc } \beta-1,4)_{\mathrm{n}}$; sialic acid \\
\hline Ulex europaeus $I$ & UEA I (gorse, furze) & L-Fuc $\alpha-1,2 \mathrm{Gal}[\mathrm{Anti}-\mathrm{O}(\mathrm{H})]$ \\
\hline Ulex europaeus II & UEA II (gorse, furze) & $(\mathrm{GlcNAc} \beta-1,4)_{2}[\mathrm{Anti}-\mathrm{O}(\mathrm{H})]$ \\
\hline Vicia fava & VFA (fava bean) & Man $\alpha-1 ;$ Glc $\alpha-1$ \\
\hline Wisteria floribunda & WFA (Japanese wisteria) & GalNAc $\alpha-1,6 \mathrm{Gal} ;$ GalNAc; Gal \\
\hline
\end{tabular}

\footnotetext{
*Adapted from references 2 and 4 .
} 
Republic), except concanavalin A and Lycopersicon esculentum which were from Sigma. Powdered lectins were dissolved in PBS ( $\mathrm{pH}$ 7.3) to a concentration of $1 \mathrm{mg} / \mathrm{ml}$ and stored at $-20^{\circ} \mathrm{C}$.

\section{Agglutination assays}

The streptococcal strains were grown and harvested, then suspended and adjusted to an $\mathrm{OD}_{540}$ of 1.0. Assays were performed in ' $U$ '-bottom, 96-well disposable polystyrene microtitration plates (Dynatech Laboratories Inc., Alexandria, VA, USA) with $50 \mu \mathrm{l}$ of lectin (original concentration $1 \mathrm{mg} / \mathrm{ml}$ ), and $50 \mu \mathrm{l}$ of bacterial suspension $\left(\mathrm{OD}_{540} 1.0\right)$. Negative controls were prepared by adding $50 \mu \mathrm{l}$ of PBS instead of lectins to the bacterial suspensions. After gentle shaking for $15 \mathrm{~min}$ at room temperature and overnight incubation at $4^{\circ} \mathrm{C}$, results were read on a test reading mirror (Dynatech Laboratories) by the settling pattern of bacteria and the presence of agglutinated cells.

\section{Procedures for cell extraction or surface modification}

Because lectin aggregation patterns may be altered by treatment of bacteria with proteases or chaotropes, or both, the streptococci were subjected to conditions that may result in cell surface modification. S. sobrinus and $S$. cricetus possess GBL, whereas $S$. mutans and $S$. sanguis are GBL-deficient. The washed bacteria in PBS were incubated with Pronase or trypsin $100 \mu \mathrm{g} / \mathrm{ml}$ for $2 \mathrm{~h}$ at $37^{\circ} \mathrm{C}$. The cells were also extracted with $6 \mathrm{M}$ guanidine hydrochloride for $2 \mathrm{~h}$ at $21^{\circ} \mathrm{C}$. Similarly, cells in water were extracted with SDS $100 \mu \mathrm{g} / \mathrm{ml}$ for $2 \mathrm{~h}$ at $37^{\circ} \mathrm{C}$. Cell suspensions were also heated in PBS at $100^{\circ} \mathrm{C}$ for $10 \mathrm{~min}$ or subjected to sonication for $1 \mathrm{~min}$ at $21^{\circ} \mathrm{C}$.

Following each treatment the cells were washed twice with water, except for the SDS-treated cells which were washed five times to remove the detergent. The cells were finally suspended in PBS before mixing with lectins.

\section{Sugar inhibition assays}

To test whether the agglutination reaction of the lectin was caused by its carbohydrate-binding capacity, inhibition of agglutination was tested with several sugars. Equal volumes $(25 \mu \mathrm{l})$ of carbohydrate, lectin and bacterial suspension were mixed to give a final inhibitor concentration of $50 \mathrm{mM}$. In the positive control, PBS replaced carbohydrate and the negative control consisted of PBS $(50 \mu 1)$ and bacterial suspension $(25 \mu \mathrm{l})$.

\section{Influence of subinhibitory concentrations (SICs)} of fluoride, citrate or antibiotics on lectin titres

A subgroup of the streptococci ( $S$. cricetus AHT, $S$. sobrinus 6715, S. mutans 10449 and S. sanguis 10556) were cultured in TSB supplemented with $5 \mathrm{~mm}$ sodium fluoride, $20 \mathrm{mM}$ sodium citrate, oxacillin $0.05 \mathrm{mg} / \mathrm{L}$ or streptomycin $10 \mathrm{mg} / \mathrm{L}$ (chemicals and antibiotics were from Sigma). Sodium fluoride and sodium citrate were dissolved in TSB before autoclaving. The antibiotics were diluted with PBS and sterilised by filtration through $0.22 \mu \mathrm{m}$ pore-size filters (Millipore Corporation, Bedford, MA, USA) then added to the autoclaved culture medium. Streptococcal cultures reached exponential phase in the presence of subinhibitory concentrations of antibiotics normally at about 2 days. Agglutination assays were performed with Con A, HPA and WGA. Cells grown in TSB without inhibitors were used as control.

\section{Rates of lectin-mediated aggregation}

Rates of lectin-mediated aggregation were investigated with a subset of the streptococcal strains ( $S$. sanguis 10556, S. mutans 10449, S. cricetus AHT and S. sobrinus 6715) and lectins (Con A, WGA and HPA) previously tested by end-point analyses in the main study. Suspensions of streptococci in PBS were mixed rapidly with lectin solutions as described previously. Absorbance readings were then made as a function of time $[21,22]$.

\section{Results}

The results of the aggregation assays are recorded in Table 2. None of the strains was aggregated with Galanthus nivalis (GNA) lectin, specific for mannose. The streptococci are not known to possess mannosecontaining surface polysaccharides, so the results with GNA were predictable. In contrast, Con A, LCH and PEA, which are specific for glucose and mannose, aggregated all the streptococci; another glucose-binding lectin, VFA, failed to agglutinate any of the text strains. Agglutination patterns varied among strains of the same species; e.g. only some strains of $S$. mutans were agglutinated by GSA-II, and similar results occurred with some strains of $S$. cricetus and LEA.

When streptococci were subjected to various treatments before mixing with lectins, titres increased in some instances, but with no treatment except for sonication did the lectin titre significantly decrease (Table 3 ). For example, the lowest concentration of Con A needed to cause agglutination of $S$. cricetus AHT was $15.6 \mu \mathrm{g} / \mathrm{ml}$. Following treatment with trypsin, the required amount of Con A was $3.91 \mu \mathrm{g} / \mathrm{ml}$ and, after Pronase digestion, this was reduced to $0.98 \mu \mathrm{g}$. $S$. mutans, $S$. sanguis and $S$. sobrinus all behaved similarly following proteolysis. Sonication, in contrast, rendered the bacteria much less reactive with lectins. For $S$. mutans 10449 , the amount of Con A needed for aggregation after sonication was $500 \mu \mathrm{g} / \mathrm{ml}$. This is a remarkably high concentration considering that only 

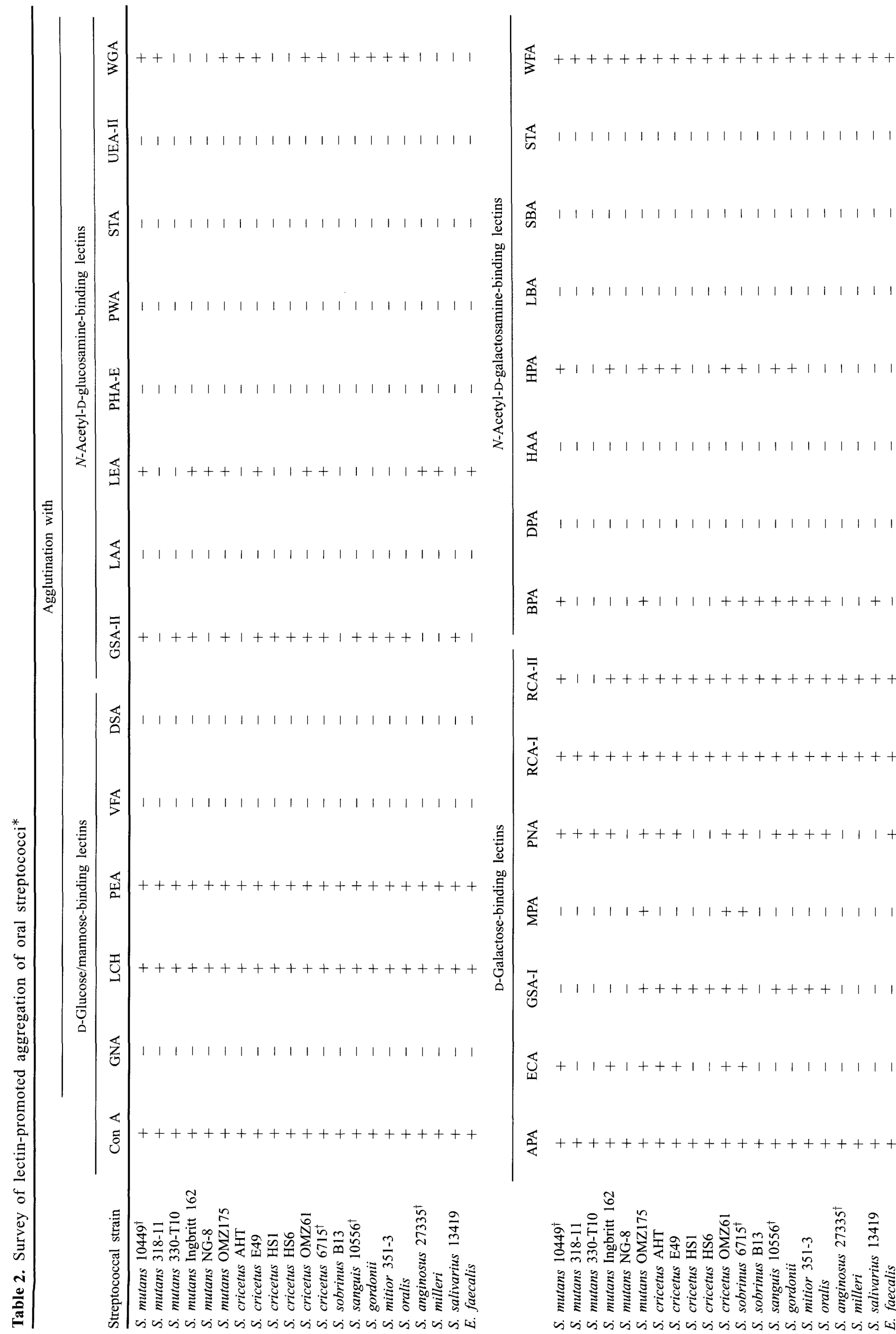

至 $+11+1+++11++1++111111$

$\begin{array}{lllllllllllllllllllll} & 1 & 1 & 1 & 1 & 1 & 1 & 1 & 1 & 1 & 1 & 1 & 1 & 1 & 1 & 1 & 1 & 1 & 1 & 1 & 1\end{array}$

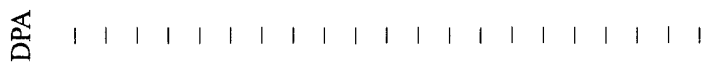

$\underset{\Delta}{\mathbb{m}}+1|1|+|1| 1+++++++1 \mid+1$

$\bigcup_{\mathscr{3}}^{\bar{d}}+11++++++++++++++++++$

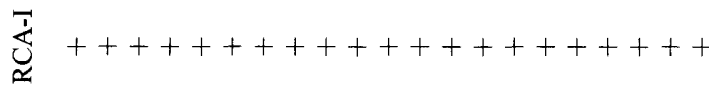

$\varliminf_{2}++++1+++11++1++++1|1|+$

$\overleftarrow{\Sigma}|1| 1|+| 1|1++1| 1|1| 1|1| 1$

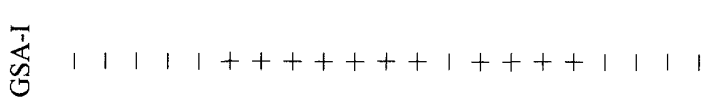

$\underset{\Xi}{\mathbb{u}}+1|+1+++1|++1|1| 1|1| 1 \mid 1$

$\overleftrightarrow{\ll}+++++++++++++++++++++$

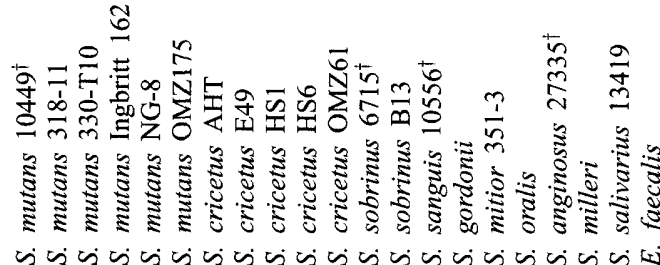




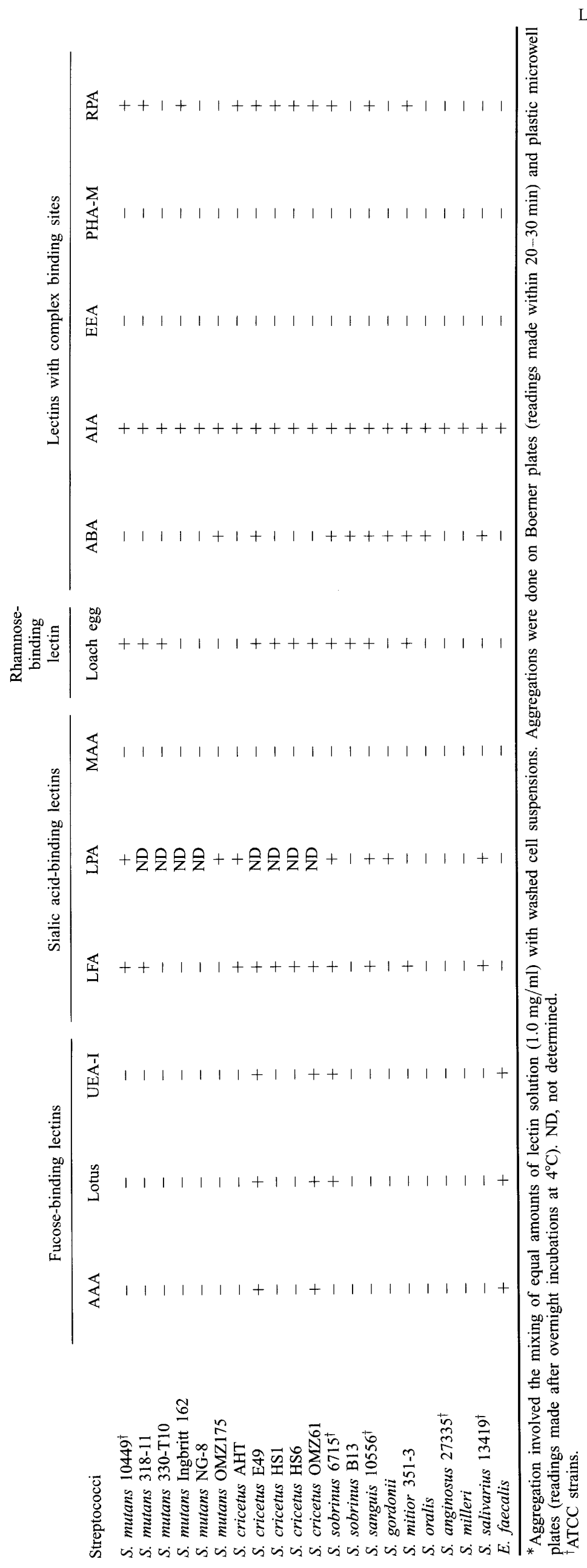


Table 3. Aggregation of oral streptococci after various treatments

\begin{tabular}{|c|c|c|c|c|c|}
\hline \multirow[b]{2}{*}{ Streptococcal strain } & \multirow[b]{2}{*}{ Treatment } & \multicolumn{4}{|c|}{ Minimum amount of lectin required for aggregation $(\mu \mathrm{g} / \mathrm{ml})$} \\
\hline & & Con $\mathrm{A}$ & HPA & PNA & WGA \\
\hline \multirow[t]{7}{*}{ S. cricetus AHT } & None & 15.6 & 3.91 & 62.5 & 62.5 \\
\hline & Guanidine $\mathrm{HCl}$ & 3.91 & 1.95 & 31.3 & 15.6 \\
\hline & Heat & 7.81 & 3.91 & 62.5 & 31.3 \\
\hline & Protease & 0.98 & 0.98 & 31.3 & 7.81 \\
\hline & SDS & 1.95 & 1.95 & 15.6 & 15.6 \\
\hline & Sonication & 125 & 31.5 & ND & ND \\
\hline & Trypsin & 3.91 & 0.98 & 31.3 & 7.81 \\
\hline \multirow[t]{7}{*}{ S. mutans 10449} & None & 15.6 & 62.5 & 62.5 & 250 \\
\hline & Guanidine $\mathrm{HCl}$ & 3.91 & 15.6 & 31.3 & 31.3 \\
\hline & Heat & 15.6 & 15.6 & 62.5 & 125 \\
\hline & Protease & 1.95 & 1.95 & 31.3 & 7.81 \\
\hline & SDS & 7.81 & 7.81 & 62.5 & 15.6 \\
\hline & Sonication & 500 & ND & ND & ND \\
\hline & Trypsin & 1.95 & 3.91 & 7.81 & 7.81 \\
\hline \multirow[t]{7}{*}{ S. sanguis 10556} & None & 15.6 & 7.81 & 125 & 15.6 \\
\hline & Guanidine $\mathrm{HCl}$ & 3.91 & 1.95 & 31.3 & 1.98 \\
\hline & Heat & 7.81 & 7.81 & 125 & 15.6 \\
\hline & Protease & 1.95 & 1.95 & 7.81 & 1.95 \\
\hline & SDS & 1.95 & 0.98 & 31.3 & 3.91 \\
\hline & Sonication & 125 & 250 & ND & 500 \\
\hline & Trypsin & 1.95 & 1.95 & 15.6 & 3.91 \\
\hline \multirow{7}{*}{ S. sobrinus 6715} & None & 15.6 & 7.81 & 250 & 62.5 \\
\hline & Guanidine $\mathrm{HCl}$ & 7.81 & 3.91 & 125 & 15.6 \\
\hline & Heat & 7.81 & 7.81 & 250 & 31.3 \\
\hline & Protease & 1.95 & 0.98 & 31.3 & 3.91 \\
\hline & SDS & 1.95 & 3.91 & 31.3 & 15.6 \\
\hline & Sonication & 125 & 250 & ND & ND \\
\hline & Trypsin & 1.95 & 1.95 & 31.3 & 7.81 \\
\hline
\end{tabular}

ND, not detected.

$15.6 \mu \mathrm{g} / \mathrm{ml}$ of the lectin was needed to elicit aggregation of the control cells.

Some streptococci produce surface-located glucanbinding lectins (GBLs). These bacteria, which include $S$. cricetus and $S$. sobrinus [20], are able to bind 6-10 $\alpha-1,6$ linked glucose residues in their active sites. When the sites are filled, the bacteria are less hydrophobic, suggesting that the $\alpha-1,6$ glucans had covered the streptococcal surfaces [23]. With this in mind, several streptococci, including $S$. mutans and $S$. sanguis, which do not possess GBLs, were mixed with glucan T-8 $100 \mu \mathrm{g} / \mathrm{ml}$ and then with HPA and WGA. The results, presented in Table 4 , show that glucan did not alter the titres of either HPA or WGA with the cells (a difference of at least two dilutions are needed for a result to be considered significant).

When various oral streptococci were grown in medium containing citrate, fluoride, oxacillin or streptomycin, it was found that lectin reactivities were altered (Table 5). Citrate caused a significant decrease in the amount of Con A needed to aggregate the bacteria. Similar results were obtained for HPA and WGA. Streptomycin, on the other hand, increased the amount of lectin (except for WGA and $S$. sobrinus 6715 ) needed to effect cell agglutination. Oxacillin lowered the amounts of lectins needed for aggregation of all bacteria tested. Based on these results, it would appear that growth conditions alter lectin reactivities.

Plots of absorbance-time relationships [21, 22] for selected streptococcal strains in the presence of Con A, WGA and HPA, are shown in Figs. 1-3. Both HPA and WGA rapidly aggregated $S$. sanguis 10556 , but neither lectin was able to rapidly aggregate $S$. mutans 10449. The latter observation was interesting in view of the fact that $S$. mutans 10449 was reactive with HPA and WGA when analysed by end-point aggregations.

Table 4. Influence of $\alpha-1,6$ glucan on lectin binding by oral streptococci*

\begin{tabular}{lcccc}
\hline & \multicolumn{4}{c}{ Minimum amount of lectin required for aggregation $(\mu \mathrm{g} / \mathrm{ml})$} \\
\cline { 2 - 5 } Streptococcal strain & HPA & HPA + glucan & WGA & WGA + glucan \\
\hline S. cricetus AHT & 3.91 & 3.91 & 62.5 & 31.5 \\
S. mutans 10449 & 62.5 & 125 & 250 & 250 \\
S. sanguis 10556 & 7.81 & 7.81 & 15.6 & 31.5 \\
S. sobrinus 6715 & 7.81 & 7.81 & 62.5 & 62.5 \\
\hline
\end{tabular}

*Glucan T-8 was employed at a final concentration of $100 \mu \mathrm{g} / \mathrm{ml}$. 
Table 5. Agglutination of oral streptococci by lectins after growth of the bacteria in media with antibiotics, citrate or fluoride*

\begin{tabular}{|c|c|c|c|c|}
\hline \multirow[b]{2}{*}{ Streptococcal strain } & \multirow[b]{2}{*}{ Medium additive } & \multicolumn{3}{|c|}{ Minimum amount of lectin $(\mu \mathrm{g})$ required for aggregation } \\
\hline & & Con A & HPA & WGA \\
\hline \multirow[t]{5}{*}{ S. cricetus AHT } & None & 15.6 & 3.91 & 62.5 \\
\hline & Citrate & 3.91 & 0.98 & 15.6 \\
\hline & Fluoride & 15.6 & 15.6 & 62.5 \\
\hline & Oxacillin & 7.81 & 1.95 & 3.91 \\
\hline & Streptomycin & 7.81 & 7.81 & 31.3 \\
\hline \multirow[t]{5}{*}{ S. mutans 10449} & None & 15.6 & 62.5 & 250 \\
\hline & Citrate & 0.98 & 3.91 & 31.3 \\
\hline & Fluoride & 31.3 & 125 & 125 \\
\hline & Oxacillin & 1.95 & 7.81 & 31.3 \\
\hline & Streptomycin & 15.6 & 500 & 250 \\
\hline \multirow[t]{5}{*}{ S. sanguis 10556} & None & 15.6 & 7.81 & 15.6 \\
\hline & Citrate & 3.91 & 0.98 & 0.98 \\
\hline & Fluoride & 15.6 & 15.6 & 15.6 \\
\hline & Oxacillin & 7.81 & 0.98 & 1.95 \\
\hline & Streptomycin & 31.3 & 15.6 & 15.6 \\
\hline \multirow[t]{5}{*}{ S. sobrinus 6715} & None & 15.6 & 7.81 & 62.5 \\
\hline & Citrate & 3.91 & 1.95 & 15.6 \\
\hline & Fluoride & 15.6 & 7.81 & 62.5 \\
\hline & Oxacillin & 3.91 & 3.91 & 7.81 \\
\hline & Streptomycin & 15.6 & 31.3 & 31.3 \\
\hline
\end{tabular}

${ }^{*}$ Growth was in TSB supplemented with $5 \mathrm{mM}$ sodium fluoride, $20 \mathrm{mM}$ sodium citrate, oxacillin $0.05 \mathrm{mg} / \mathrm{L}$ or streptomycin $10 \mathrm{mg} / \mathrm{L}$.

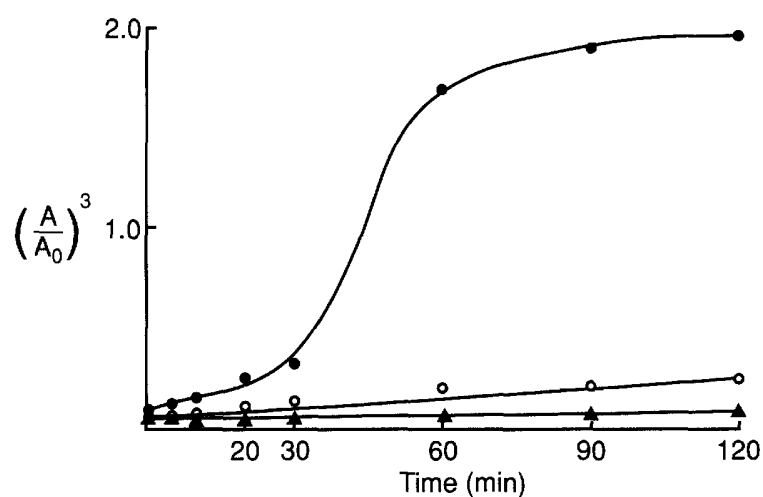

Fig. 1. Aggregation of oral streptococci by Con A showing that Con A readily aggregated $S$. sobrinus (O) 6715 and only slowly aggregated S. cricetus AHT (O) and $S$. sanguis 10556 (А).

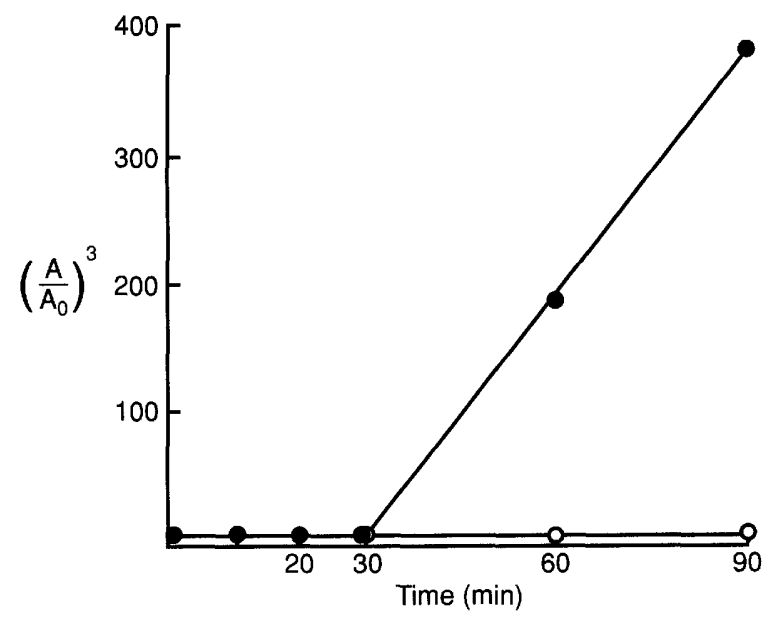

Fig. 2. Aggregation of oral streptococci by wheat-germ agglutinin. Results in Table 2 revealed that both $S$. mutans 10449 and $S$. sanguis 10556 were aggregated by WGA. Kinetic measurements of the interaction showed that $S$. sanguis $(0)$ was rapidly aggregated by the lectin but $S$. mutans (O) was not.

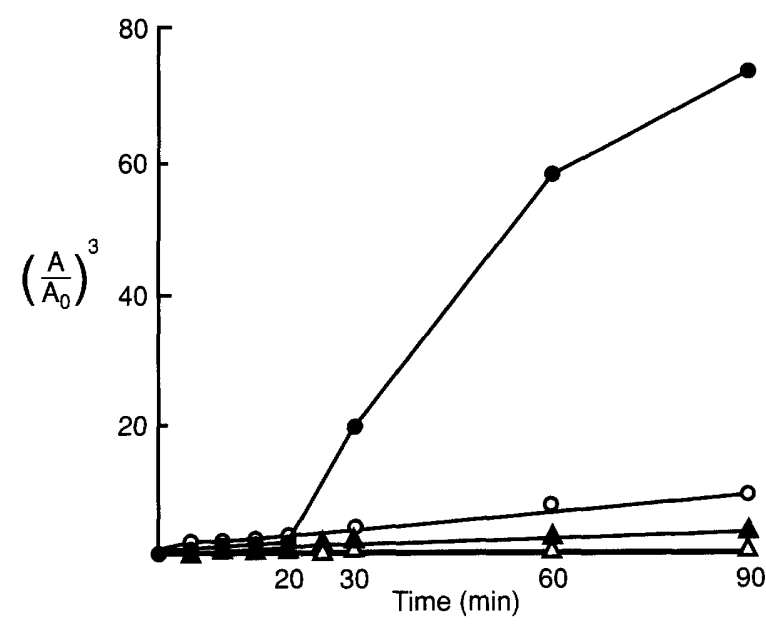

Fig. 3. Aggregation of oral streptococci by Helix pomatia lectin. The HPA readily aggregated $S$. sanguis $10556(0)$ and only slowly aggregated S. sobrinus $6715(O)$ and $S$. cricetus $A H T(\boldsymbol{\Delta})$. The lectin failed to agglutinate $S$. mutans $10449(\triangle)$.

\section{Discussion}

Results from this study reveal that oral streptococci can be aggregated by soluble lectins, although the aggregation patterns are unpredictable within species, e.g., variation occurred among strains of $S$. mutans (Table 2 ). It is known that isolates of a given species may yield their own unique aggregation patterns with lectins, and these unique patterns can be employed in epidemiological studies $[8,9]$.

Another interesting finding of the study is that lectins of very similar specificities may or may not aggregate a particular streptococcal strain. Wheat-germ agglutinin has a mol.wt of 43200 and binds terminal $\beta-N$ - 
acetylgucosamine. On the other hand, the lectin from Solanum tuberosum has a mol.wt of 100000 and also reacts with GlcNAc, but preferentially with (GlcNAc) $)_{3}$. Furthermore, the lectin GSA-II from Griffonia simplicifolia has a mol.wt of 113000 and is able to bind $\alpha$ - or $\beta$-linked GlcNAc. Interestingly, WGA and GSA-II aggregated $S$. mutans strains not recognised by STA. The STA, in contrast, was able to aggregate none of the $S$. mutans strains tested (Table 2 ). It is likely that WGA and GSA-II are complexing with PG that contains a glycan of $\beta$-linked GlcNAc and muramic acid. The latter sugar is known to bind with WGA and other GlcNAc-specific lectins [24, 25]. Sizemore et al. [26] suggested that WGA may be able to distinguish gram-positive (WGA-reactive) from gram-negative bacteria. It has been reported that not all gram-positive bacteria are WGA-reactive [27] and some gram-negative bacteria are aggregated by the lectin [5]. At present, it is not known why some oral streptococci do not react with lectins of similar specificities. Most oral streptococci produce cell wall-associated proteins and most produce PG-bound polysaccharides [28-31]. These surface stuctures may mask potential lectin receptors, or they may serve as receptors for other lectins. As discussed later, protease and protein denaturing conditions modify the extent of lectin-dependent aggregation of several streptococci.

It is known that the growth of oral streptococci in the presence of antibiotics or chelating agents causes the bacteria to increase or decrease GBL activities [32, 33]. Furthermore, an increase in GBL is associated with a decrease in surface hydrophobicity, whereas a decrease in GBL is mirrored by an increase in hydrophobicity. Streptomycin and citrate cause a decrease in GBL, whereas oxacillin causes an increase when these agents are added at subinhibitory concentrations to $S$. cricetus and $S$. sobrinus cultures. When oral streptococci were grown in the presence of these agents, and with fluoride, and tested for their reaction with lectins, the results were unpredictable. Streptomycin caused reactivity with Con A and HPA to decrease in some cases and increase in others, depending on the organism and the lectin. Citrate and oxacillin tended to lower the lectin concentrations needed for aggregation. It is possible that growth in media with citrate or oxacillin causes an increase in cell wall polysaccharide or a decrease in surface structures that may mask lectin receptors. Fluoride generally caused the bacteria to be less reactive with Con A or HPA.

The extraction or enzymic treatment of streptococci may be expected to alter lectin aggregation patterns [4, 34-38], as streptococcal surfaces possess both hydrophobic and hydrophilic molecules [36]. Proteases might be expected to remove proteins, leaving exposed PG and group polysaccharides, while sonication would remove adventitiously bound medium components or non-covalently bound secreted molecules. Guanidine hydrochloride is a protein solvent, capable of removing loosely attached proteins and SDS is capable of removing most non-covalently attached surface structures. When the streptococci were subjected to guanidine, heat, SDS, sonication and Pronase, washed, suspended and treated with lectins, the results were predictable. In most cases, lectin reactivity was increased as determined by the decreased amount of lectin required to effect aggregation (Table 3). All treatments, except sonication, caused a decrease in the amount of lectin needed for aggregation. The results for sonication may be explained partially by the fact that ultrasound is capable of 'breaking' elongated structures. Therefore, sonication may have caused the loss of surface polysaccharides which are extended linear structures, unlike globular proteins. Gray et al. [14] observed that sialidase treatment and mild acid hydrolysis (which destroys sialic acids), enhance the interaction between WGA and group B streptococci. Trypsinisation also enhances the recognition of serotype-specific polysaccharides in $S$. mutans by antibodies [16]. Boiling, trypsin and acid treatments all increase the ability of lectins to aggregate streptococci, including the 'milleri' group [39].

A part of the present study was to gain a better understanding of bacterial surfaces by use of lectin probes. As pointed out earlier, some oral streptococci, when cultured in media with fluoride, citrate or antibiotics, have lowered glycan-binding lectin activities. In contrast, other antibiotics increase the expression of GBL on the surface of $S$. cricetus and $S$. sobrinus. The GBL is a protein situated on the PG of the streptococci and as far as is known, is not glycosylated and able to serve as a receptor of exogenously added lectins. In work in this laboratory, Mata [23] observed that when $\alpha-1,6$ glucan was added to $S$. sobrinus 6715 or $S$. cricetus AHT, the cells became more 'hydrophilic', as determined by adhesion to plastics and hydrocarbons or by aggregation with ammonium sulphate. When $\alpha-1,6$ glucan was added to $S$. sobrinus or $S$. cricetus, and the suspension was subjected to lectin aggregation, it was found that the glucan was unable to mask (or expose) lectin-reactive sites (Table 4). These results suggest that hydrophobic probes, but not lectins, may detect surface changes on a bacterium - probably because the latter can probe only for carbohydrate receptors.

Bacterial aggregation assays with lectins on a glass plate or in a plastic well are essentially end-point assays, which are free of kinetic considerations and are useful for screening. However, kinetic assays are required to obtain results to establish the relative reactivities of different bacterial species and strains with various lectins. In Fig. 1, it was shown that $S$. sanguis 10556 could be readily aggregated by HPA, whereas $S$. cricetus AHT, S. mutants 10449 and $S$. sobrinus 6715 were aggregated slowly. All of the bacteria were positive with HPA in plate assays (Table 
2). Similar results were obtained when WGA was used to aggregate $S$. sanguis 10556 and $S$. mutans 10449 . It is possible that the kinetic approach to detecting lectin-streptococcus complexes would be useful when distinguishing one streptococcal strain from another, but many additional assays will be required.

This is the first comprehensive examination of oral streptococci-lectin interactions and the results suggest that genus or species identification with a lectin probe is impossible. Nevertheless, it is clear that lectin receptors exist on all the streptococci and receptors can be exposed by chaotropic agents or protease, although this does not enhance specificity. Lectin receptors are not modified when surface proteins, such as GBLs, are complexed with ligands. The known structures [28-31] of some of the streptococcal surface polysaccharides are repeating units of 4-6 carbohydrates. Lectins with specificities for several carbohydrates linked in a sequence would be useful in defining surface characteristics of oral streptococci.

This research was supported by the US-Mexican Science Foundation.

\section{References}

1. Corbel MJ, Cockrem DS, Brewer RA. Differentiation of smooth and rough Brucella strains by lectins. Vet Rec 1983; 113: $261-$ 262.

2. Slifkin M, Doyle RJ. Lectins and their application to clinical microbiology. Clin Microbiol Rev 1990; 3: 197-218.

3. Corbel MJ, Gill KPW. Lectin agglutination of thermophilic Campylobacter species. Vet Microbiol 1987; 15: 163-173.

4. Doyle RJ. Introduction to lectins and their interactions with microorganisms. In: Doyle RJ, Slifkin M (eds) Lectin-microorganism interactions. New York, Dekker. 1994: 1-65.

5. Doyle RJ, Nedjat-Haiem F, Keller KF, Frasch CE. Diagnostic value of interactions between members of the family Neisseriaceae and lectins. J Clin Microbiol 1984; 19: 383-387.

6. Curtis GD, Slack MPE. Wheat-germ agglutination of Neisseria gonorrhoeae. A laboratory investigation. Br J Vener Dis 1981; 57: $253-5$.

7. Wong KH, Skelton SK, Feeley JC. Interaction of Campylobacter jejuni and Campylobacter coli with lectins and blood group antibodies. J Clin Microbiol 1985; 22: 134-135.

8. Schalla WO, Whittington WL, Rice RJ, Larsen SA. Epidemiological characterization of Neisseria gonorrhoeae by lectins. $J$ Clin Microbiol 1985; 22: 379-382.

9. Vazquez JA, Berron S. Lectins agglutination test as an epidemiological marker for Neisseria gonorrhoeae. Genitourin Med 1990; 66: 302.

10. Leopold K, Fischer W. Separation of the poly (glycerophosphate) lipoteichoic acids of Enterococcus faecalis Kiel 27738, Enterococcus hirae ATCC 9790 and Leuconostoc mesenteroides DSM 20343 into molecular species by affinity chromatography on concanavalin A. Eur J Biochem 1991; 196: 475-482.

11. Ryc M, Wagner B, Wagner M, Bicova R. Electron microscopic localization of lipoteichoic acid on group A streptococci. Zentrabl Bakteriol Hyg 1988; A269: 168-178.

12. Slifkin M, Gil GM. Identification of group C streptococcal antigen extracts with lectin-bound polystyrene particles. J Clin Microbiol 1984; 19: 83-84.

13. Köhler W, Prokop O, Kühnemund O. Routine identification of group-C streptococci by means of an agglutinin (protectin) from the albumen gland of the edible snail, Helix pomatia. J Med Microbiol 973; 6: 127-130.

14. Gray BM, Dillon HC, Pritchard DG. Interaction of group B streptococcal type-specific polysaccharides with wheat germ agglutinin and other lectins. I Immunol Methods 1984; 72: $269-277$.
15. Kashket S, Guilmette KM. Aggregation of oral streptococci in the presence of concanavalin A. Arch Oral Biol 1975; 20: 375379.

16. Hamada S, Gill K, Slade HD. Binding of lectins to Streptococcus mutans cells and type-specific polysaccharides, and effect on adherence. Infect Immun 1977; 18: 708-716.

17. Coykendall AL. Classification and identification of the viridans streptococci. Clin Microbiol Rev 1989; 2: 315-328.

18. Beighton D, Russell RRB, Whiley RA. A simple biochemical scheme for the differentiation of Streptococcus mutans and Streptococcus sobrinus. Caries Res 1991; 25: 174-178.

19. Liebana J, Parejo E, Castillo A, Gutierrez J. Phenotypic characterization of oral streptococci by classical methods. Microbios 1993; 76: 7-18.

20. Drake D, Taylor KG, Bleiweis AS, Doyle RJ. Specificity of the glucan-binding lectin of Streptococcus cricetus. Infect Immun 1988; 56: 1864-1872.

21. Flemming $C$. The kinetics of lectin-mediated cell aggluntination. Adv Lectin Res 1991; 4: 97-121.

22. Duszyk M, Kawalec MK, Doroszewski J. Quantitative study of lectin-mediated cell aggregation. In: Bøg-Hansen TC, Breborowicz J (eds) Lectins - Biology, Biochemistry, Clinical Biochemistry, vol 4. Berlin, Walter de Gnyter. 1985: 307-312.

23. Mata L, Drake D, Doyle RJ. Modification of surface properties of oral streptococci by $\alpha-1,6$-glucans. Colloids and Surfaces (Biointerfaces) 1997; 8: 295-302.

24. Ayouba A, Chatelain C, Rougé P. Legume lectins interact with muramic acid and $\mathrm{N}$-acetylmuramic acid. FEBS Lett 1991; 289: $102-104$.

25. Ayouba A, Martin D, Rougé P. Recognition of muramic acid and $\mathrm{N}$-acetylamuramic acid by leguminosae lectins: possible role in plant--bacteria interactions. FEMS Microbiol Lett 1992; 92: $41-46$.

26. Sizemore RK, Caldwell JJ, Kendrick AS. Alternate gram staining technique using a fluorescent lectin. Appl Environ Microbiol 1990; 56: 2245-2247.

27. Cole HB, Ezzell JW, Keller KF, Doyle RJ. Differentiation of Bacillus anthracis and other Bacillus species by lectins. J Clin Microbiol 1984; 19: 48-53.

28. Abeygunawardana C, Bush CA, Tjoa SS, Fennessey PV, McNeil MR. The complete structure of the capsular polysaccharide from Streptococcus sanguis 34. Carbohydr Res 1989; 191: 279--293.

29. Abeygunawardana $\mathrm{C}$, Bush CA, Cisar JO. Complete structure of the polysaccharide from Streptococcus sanguis J22. Biochemistry 1990; 29: 234-248.

30. Abeygunawardana $\mathrm{C}$, Bush CA, Cisar JO. Complete structure of the cell surface polysaccharide of Streptococcus oralis ATCC 10557: a receptor for lectin-mediated interbacterial adherence. Biochemistry 1991; 30: 6528-6540.

31. Cisar JO, Sandberg AL, Abeygunawardana C, Reddy GP, Bush CA. Lectin recognition of host-like saccharide motifs streptococcal cell wall polysaccharides. Glycobiology 1995; 5: 655662.

32. Wu Q, Wang Q, Taylor KG, Doyle RJ. Subinhibitory concentrations of antibiotics affect cell surface properties of Streptococcus sobrinus. J Bacteriol 1995; 177: 1399-1401.

33. Lü-Lü, Singh JS, Galperin MY, Drake D, Taylor KG, Doyle RJ. Chelating agents inhibit activity and prevent expression of streptococcal glucan-binding lectins. Infect Immun 1992; 60 3807-3813.

34. Charland N, Kellens JTC, Caya F, Gottschalk M. Agglutination of Streptococcus suis by sialic acid-binding lectins. J Clin Microbiol 1995; 33: 2220-2221.

35. Kellens JTC, Jacobs JA, Peumans WJ, Stobberingh EE. The agglutination of $\beta$-haemolytic streptococci by lectins. $J$ Med Microbiol 1993; 39: 440-445.

36. Doyle RJ, Rosenberg M, Drake D. Hydrophobicity of ora bacteria. In: Doyle RJ, Rosenberg $M$ (eds) Microbial cell surface hydrophobicity. Washington DC, American Society for Microbiology. 1990

37. Motlová J, Wagner M, Jelínková J. A search for new group-B streptococcal serotypes. J Med Microbiol 1986; 22: 101-105.

38. Wagner M. Interaction of wheat-germ agglutinin with streptococci and streptococcal cell wall polymers. Immunobiology 1979; 156: 57-64.

39. Kellens JTC, Jacobs JA, Peumans WJ, Stobberingh EE Agglutination of "Streptococcus milleri" by lectins. J Med Microbiol 1994; 41: 14-19. 